\title{
PARENTS' DETERMINANTS BUYING INTENT ON ENVIRONMENTALLY FRIENDLY CHILDREN'S CLOTHING
}

\author{
Siti Shukhaila Shaharuddin * \\ Faculty of Creative Technology and Heritage, Universiti Malaysia Kelantan \\ Marzie Hatef Jalil \\ Faculty of Applied and Creative Arts, Universiti Malaysia Sarawak
}

\begin{abstract}
Fast-fashion products encourage parents to spend more on their children's necessities. As a result, children's clothing consumption is increasingly higher in a family due to child growth and change of needs. Due to the short lifespan of children's clothes, the waste of clothing is increasing rapidly. This research aims to study the opinion of parents and the acceptance of children's environmental-friendly clothing. The research examined parents' buying patterns such as shopping frequency, disposal practices and the purchase of child clothing experience. This work has embraced the idea of eco-fashion design to examine the clothing needs of children and the knowledge of the parents. Hence, a quantitative analysis was applied to research among parents in January 2020 in Malaysia. This research contributes to academic results about parents' decision-making on the children clothing subject. The findings showed that parents were aware of the idea of sustainable apparel; the cost, quality, design, and health issues were the most significant factors that influenced consumer's decisions to purchase children's clothing. Sustainable children's clothing was preferred by parents as it had multiple benefits which impacted children's health, preserves the environment as well as cost and time effective. For future research, further exploration relating to disposal and sustainable clothing design for children is suggested.
\end{abstract}

Keywords: Children's clothing, Clothing waste, Clothing disposal, Environmentally friendly clothing, Sustainable design, Buying intention.

Received: 7 August 2020

Accepted: 4 May 2021

https://doi.org/10.33736/ijbs.4326.2021

\section{INTRODUCTION}

The needs for children's products continue to shift rapidly, which is why children's clothing, equipment acquisition and consumption of children have received some attention from recent studies (Gam et al., 2010; Haluk Köksal, 2007; Sego, 2010; Shaharuddin \& Jalil, 2021; Zhang, 2018). In the children's clothing market, the volume is expected to be $69,682.59$ million pieces by 2023 , when the average price per unit on the children's clothing market is estimated to be US \$

- Corresponding author: Senior Lecturer at the Faculty of Creative Technology and Heritage, University Malaysia Kelantan (UMK), Malaysia; Email: juju105@gmail.com. 
4.60 in 2020 (Statista, 2020). Most parents purchase new items and dispose of the old ones. Hence, the disposal of children's clothing makes them useless and impractical. Moreover, adult-style children's clothing, which adopted single-coloured, reflecting tight tailoring effect, in particular the use of many rivets, beads, chains and other complex decorative elements, resulting in the issue of health problems, appears to be inadequate for children (Zhang, 2018). Clothing quality can affect children's physical and mental health. The low quality of children's clothing should, therefore, be prohibited in the clothing industry.

The sustainable design integrates technology, economic, environmental, and social factors. Thus, sustainable design deliberates the environmental benefits, social wellbeing and economic concerns over a product's entire lifecycle. Gam et al. (2010) stated that women with at least one child are interested in sustainable or eco-friendly products. This can be very beneficial for children and may also inspire parents to act in an environmentally friendly manner. Previous research mainly focused on the design strategies of multifunctional clothing concerning sustainability development in the fashion market (Cao et al., 2014; Jalil \& Shaharuddin, 2019a; Koo et al., 2014; Rahman \& Gong, 2016). It is understood that excess of children's items consumed, emotions, clothes disposal practices and their willingness to possess sustainable clothing will provide a wealth of insights into sustainability.

On the plus side, MATRADE's Lifestyle Director Mr Abu Bakar Yusof during the Little Me Showcase, Malaysia External Trade Development Corporation (2016) said that the demand for global children's wear had been increasing steadily with a market value of approximately US $\$ 157$ billion. The high demand for children's clothing encourages more innovation of research. Therefore, this research seeks to examine Malaysian parents' determinants of buying intent of sustainable clothing, their interest in purchasing eco-friendly children's clothing and their purchasing preferences. Hence, the current research aims to:

- $\quad$ Explore the frequency of purchases, cost of shopping and disposal of children's clothing among parents.

- Investigate factors affecting the selection of sustainable (eco-friendly) clothing in shopping, particularly multifunctional clothing for children.

- Determine the relationship between the variables that influenced shopping decisions with respect to sustainable children's clothing and the parent's demographic.

A survey was conducted to investigate the preferences of parents. SPSS 23 and SmartPLS were used to analyze the data and results. The following sections provide a brief review of consumer research. This is followed by an explanation of the methodology and findings from the study. The article concludes by summarizing and explaining the consequences.

\section{LITERATURE REVIEW}

\subsection{Children's Clothing Disposal and Sustainable Purchasing Factors}

The fast-fashion concept suggested that increasing new purchases of children's clothing and disposing of old clothes may have different reactions such as; (1) low-value objects in the trash bin, (2) higher-value objects without plans, (3) things of less personal significance and usefulness to others are recycled by giving, selling or donating and (4) important items are given away (Sego, 
2010). Indeed, one of the concerns that have the biggest influence on sustainability is the disposal of clothing, which has a significant environmental impact since the materials employed are hazardous to the environment and health (Kamis et al., 2018). A previous study found few environmental concerns in the relationship between customers' purchasing intentions for ecofriendly children's apparel and the garment industry (Rhee \& Johnson, 2019). In line with this discussion, we hypothesize that:

\section{$H_{1}$ : Children's clothing consumption and disposal have a direct relationship with determinants of buying intent on environmentally friendly children's clothing.}

The local Malaysian consumers are unaware of the environmental impacts of the clothing industry (Jalil \& Shaharuddin, 2019b). Moreover, the satisfaction of the children's clothing market is primarily evaluated for its appearance, function, price, durability, and comfort at first sight. On the other hand, with regards to sustainable clothing products for children, Berry et al. (2020) mentioned that parents choose organic cotton clothes because of the quality and better tactile feel which is important for children. Likewise, Gam et al. (2010) research framework demonstrated how mothers' environmental concerns, environmental purchasing and recycling behaviour all have a significant impact on their involvement in children's clothing. In fact, Haluk Köksal (2007) stated that the important factors affecting the decision of parents to buy children's clothing are the price value, quality feature, design of clothes, convenience and size of the clothing as regards fitting to the body. The study also found that the price is not a main factor in the purchase of children's clothing, and many buyers also saw higher prices as a quality and safety guarantee. Therefore, the following hypothesis is proposed for the current study's context:

\section{$\mathrm{H}_{2}$ : Parent's experience toward sustainable children's clothing has a direct relationship with determinants of buying intent on environmentally friendly children's clothing.}

\subsection{Children's Clothing Design Properties}

Children's products should meet physical and psychological needs which emphasise the new shapes, unique appearances, and others to attract children (Haluk Köksal, 2007). Children not only like clothes but enjoy buying them (Lindstrom et al., 2004). However, complicated clothing design can cause visual fatigue. Therefore, children's clothing design should adopt a flexible and simple style and cultivate children's aesthetic consciousness (Bezerra et al., 2017). Designers should pay attention to comfort, convenience, safety, and more attention should be paid to actual demand, production costs, adhere to the people-oriented design concept (Jalil \& Shaharuddin, 2020), in line with the law of children's growth and ensure physical and mental health (Zhang, 2018). Cui et al. (2011) stated that colour is the most effective visual transmission element of the children's product. Children have sensitivity to colour which can stimulate their desire to buy, emotion and enhance imagination. In particular, the intricate colour mixing of current fashion styles is not conducive to children's recognition and memory, and it can complicate children's thoughts and perceptions, fear and irritability (Yu et al., 2018). Besides that, multifunctional clothing is growing as a sustainable product in the textile and fashion industries. This kind of clothing design is defined to perform multiple functions toward more utilization (Cunha \& Broega, 2009). This trend would increase the rate of use, the lifespan of the clothing and reduce disposal (Koo et al., 2014). Therefore, multifunctional clothing can be alternate revenue streams for the fashion industry as a positive idea 
for the young consumer market toward sustainability (Rahman \& Gong, 2016). Based on the discussion in the literature on this subject, we hypothesize that:

\section{$H_{3}$ : Parents' opinion on the design properties of children clothing has a direct relationship with determinants of buying intent on environmentally friendly children's clothing.}

Moreover, Haluk Köksal (2007) showed that there is a positive relationship between the demographic characteristics of the respondents and the factors that affect their shopping decisions regarding sustainable children's clothing.

The hypotheses formulated regarding children's clothing are developed based on the discussed literature. Thus, a research framework is created following the "willingness to purchase organic cotton clothing's study" (Gam et al., 2010) which is shown in Figure 1:

Figure 1: Research framework

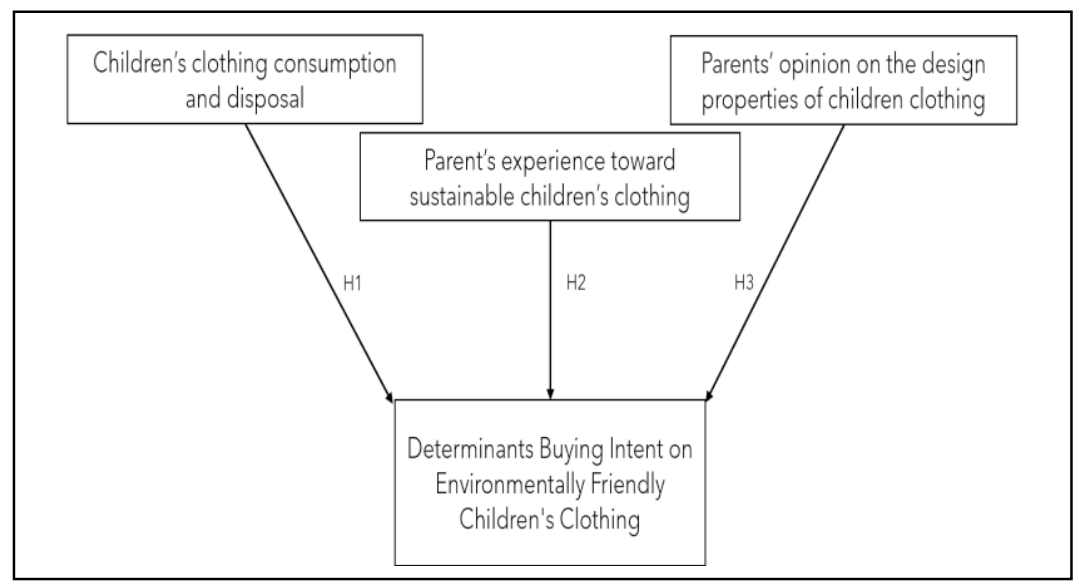

\section{METHODOLOGY}

This study investigates and defines a solution for children's clothing toward sustainability. The design team seeks to identify and analyse the issues in the field of eco-fashion. A set of questionnaires was developed to investigate the sustainability of children's clothing and consumer preferences. Hence, to understand the parent's considerations when buying children's clothing, focusing mainly on profit, environmental conservation, and consumer needs. In similar research, Berry et al. (2020) used 150 sample sizes of participants and Gam et al. (2010) with 174 participants in a sustainable children's clothing investigation. Delice (2010) stated that sampling with purposeful random adds credibility to a sample when the potential purposeful sample is larger than one can handle which uses small sample sizes, thus the result is credible, not representativeness or the ability to generalize. With better planning and smaller sample size, it is possible to get more reliable results. The maximum sample size is frequently used to be around $10 \%$ of the population. However, in most studies, the sample size is determined effectively by the 
nature of the data analysis proposed and the estimated response rate. In this research, the plan was to survey 200 Malaysian parents. However, only 160 responded to the questionnaire.

Thompson (2006) equation was used to calculate the sample size, from the next formula (1):

$$
n=\frac{N p(1-p)}{\left[\left[N-1\left(d^{2} \div z^{2}\right)\right]+p(1-p)\right]}
$$

n: sample size; N: Population size; z: $95 \%$ Confidence level (1.96); d: Error proportion (0.05); p: Probability $(50 \%)$. The One-Sample Kolmogorov-Smirnov Test was also used in the sampling to see if a sample originates from a certain distribution and whether a sample comes from a normally distributed population.

Parents with children aged 3 to 7 years old were chosen as the target audience. A pre-test was administered to parents in Kuching, Malaysia. The information was gathered through face-to-face surveys in Malaysia in January 2020 which comprised 24 questions. The survey questions elicited parent perspectives on purchasing sustainable/multifunctional children's apparel designs. The questions are divided into four areas including; (1) children's clothing consumption and disposal, (2) opinions and experience towards sustainable and multifunctional children's clothing design, (3) opinions of parents on the design properties of children's clothing and (4) socio-demographic.

(1) The respondents buying patterns for their children are shopping duration and spending money on children's clothing. The contents of questions were adapted from previous literature (Bezerra et al., 2017; Gam et al., 2010; Haluk Köksal, 2007; Sego, 2010; Zhang, 2018), with the wording changed to fit this study, which is the result of hypothesis one in Table 2.

(2) The respondents' views on their children's clothes covered their experiences purchasing ecofriendly fashion as well as their attitudes on multifunctional children's clothing. The questions were referred from previous literature (Gam et al., 2010; Zhang, 2018), where hypothesis two resulted in Table 3.

(3) The team designed multifunctional prototypes of children's clothing based on famous cartoon characters and well-known among children. During the survey, the respondents were explained about the eco-friendly materials, the ability of these clothing to transform into bags and their multifunctionality before they answered the questionnaires. Malaysian children are drawn to vivid and eye-catching colours as well as cartoon characters (Chong, 2007). Cartoon characters like Doraemon and Chase for example are in blue. Blue is said to be the coolest and most soothing colour. On the other side, most females like pink such as Skye in the Paw Patrol characters. Pink is a lovely colour that represents love and beauty. SpongeBob's characteristic colour is yellow, which symbolizes truth and harmony while making children joyful and cheery. This part of the questionnaire included visual questions with Likert-scale value of 1 to 5 that analyses the prototype design; (1) the cartoon characters, (2) typographical and (3) simple design clothes to determine which style of children's clothing design is preferred. Therefore, hypothesis three results are in Table 7. 
(4) The demographic variables used to assess respondents' profiles included gender, income, education and employment status, and the results are in Table 1. This questionnaire took about 5 minutes for each respondent to complete the survey. Descriptive statistics, reliability, validity, and correlations using SPSS 23 and SmartPLS were computed for each variable to obtain the results. The significance level was set at $95 \%$. Therefore, the relationships between demographic variables and factors that influence parents' purchasing decisions on children's clothes have been examined using Chi-square analytical approaches.

\section{RESULTS}

The problem was identified as excessive clothing consumption, as well as an increase in clothing and textile waste in children's clothing production. The data from this survey were mainly obtained from a convenience sample of parents who have children through a snowball sampling test in Malaysia.

As shown in Table 1, a total of 144 usable data out of 160 were collected including 23 males (23\%) and 121 females (84\%). Many participants have one and two children (29.9\%, and 50.7\%, respectively). The largest percentage $(38.9 \%)$ is the bachelor's degree holder. The most $(47.2 \%)$ monthly family income of the respondents is reported between RM 500 and RM 2,000. 47.2\% of respondents purchase children's clothing every 3 to 4 months in a year, where most of them (51.4\%) spend RM 51-100 each time they go shopping.

Table 1: Demographic profile of respondents $(\mathrm{N}=144)$

\begin{tabular}{|c|c|c|c|}
\hline \multicolumn{2}{|c|}{ Question } & Frequency & Per cent \\
\hline \multirow{2}{*}{ Gender } & Female & 121 & 84.0 \\
\hline & Male & 23 & 16.0 \\
\hline \multirow{5}{*}{$\begin{array}{l}\text { How many children do you } \\
\text { have? }\end{array}$} & One & 43 & 29.9 \\
\hline & Two & 73 & 50.7 \\
\hline & Three & 24 & 16.7 \\
\hline & More & 4 & 2.8 \\
\hline & Less than high school & 10 & 6.9 \\
\hline \multirow{3}{*}{$\begin{array}{l}\text { What is the highest level of } \\
\text { education you have } \\
\text { completed? }\end{array}$} & High school graduate & 40 & 27.8 \\
\hline & $\begin{array}{l}\text { College graduate (bachelor's } \\
\text { degree, BA, BS) }\end{array}$ & 56 & 38.9 \\
\hline & Professional degree & 38 & 26.4 \\
\hline \multirow{5}{*}{ Monthly Income } & RM 500 - RM 2, 000 & 68 & 47.2 \\
\hline & RM 2, 001 - RM5, 000 & 53 & 36.8 \\
\hline & RM 5, 001 - RM 10,000 & 16 & 11.1 \\
\hline & More than RM 10, 001 & 7 & 4.9 \\
\hline & Once a month & 30 & 20.8 \\
\hline \multirow{4}{*}{$\begin{array}{l}\text { How often do you purchase } \\
\text { clothing for your children? }\end{array}$} & Quarterly & 68 & 47.2 \\
\hline & Once every 5-6 months & 20 & 13.9 \\
\hline & $\begin{array}{l}\text { Occasionally once or twice a } \\
\text { year }\end{array}$ & 13 & 9.1 \\
\hline & Other & 13 & 9.0 \\
\hline \multirow{2}{*}{$\begin{array}{l}\text { On average, how much do } \\
\text { you spend on children's }\end{array}$} & Less than RM 50 & 6 & 4.2 \\
\hline & RM 51 -RM100 & 74 & 51.4 \\
\hline
\end{tabular}




\begin{tabular}{lcccc} 
clothing each time you go & RM 101 - RM 200 & 22 & 15.3 \\
shopping? & RM 201 - RM 500 & 35 & 24.3 \\
& & More than RM 501 & 7 & 4.9 \\
\hline
\end{tabular}

As shown in Table 2, most parents will dispose of unwanted children's clothes in sustainable ways. Most of them $(65.47 \%)$ give away clothes to family or friends, some of them $(59 \%)$ reuse clothes for new purposes and $(52.7 \%)$ about half of the group donate clothes to the charity organization. The child growth and change in height and weight (31.2\%) and ripped out clothes $(28.5 \%)$ are the main reasons for disposing of their children's clothes.

As shown in Table 3, the largest respondent (50\%) had not purchased sustainable clothing for children that "lack of knowledge" and "not available" were the most reasons they mentioned. On the other hand, $25 \%$ of respondents had purchased sustainable children clothing that was influenced by factors such as health issues, quality, and design $(91.6 \%, 77.7 \%$ and $55.5 \%$, respectively). Interestingly, most of the respondents $(84.7 \%)$ were interested in purchasing multifunctional children clothing and no one had negative feedback on this question.

Table 2: Respondent's patterns of consumption and disposing of clothes $(\mathrm{N}=144)$

\begin{tabular}{llll}
\hline \hline Question & & Frequency & Per cent \\
\hline & Donation to the charity & 76 & 52.7 \\
& organizations & & \\
& Give away to the family/friends & 94 & 65.27 \\
How do you dispose of & Put in the fabric recycling bin & 11 & 7.63 \\
unwanted children's clothes? & Reuse for a new purpose & 85 & 59 \\
& Selling for online auction & 27 & 18.7 \\
& Throw away into any garbage bins & 8 & 5.55 \\
& available & 22 & 15.3 \\
\hline & Others & 41 & 28.5 \\
& Ripped out & 12 & 8.33 \\
& Out of fashion & 31.2 \\
What is the main reason that you & Child growth and change in height & 45 & 5.55 \\
dispose of your children's clothes? & Purchased for only one event & 8 & 22.9 \\
& To make space for new clothing & 33 & 3.47 \\
\hline \hline
\end{tabular}


Table 3: Parent's experience toward sustainable children's clothing ( $\mathrm{N}=144)$

\begin{tabular}{llll}
\hline \hline Question & & Frequency & Per cent \\
\hline Have you purchased eco-friendly & I do not know & 36 & 25.0 \\
clothing for your children before? & No & 72 & 50.0 \\
& Yes & 36 & 25.0 \\
& Expensive & 18 & 25 \\
If No, why not? & Poor quality & 11 & 15.2 \\
& Lack of knowledge & 65 & 90.2 \\
& Not available & 63 & 87.5 \\
& Quality & 28 & 77.7 \\
If Yes, what are your reasons for & Design and colour & Price & 55.5 \\
purchasing such clothes? & Health issues & 8 & 22.2 \\
& Environmental Protection & 33 & 91.6 \\
& Other & 6 & 16.6 \\
Are you willing to purchase & I do not know & 11 & 30.5 \\
Multifunctional Clothing for your & & 22 & 15.3 \\
children? & Yes & & \\
& No & 122 & 84.7 \\
\hline \hline
\end{tabular}

The relations between the demographic features of the respondents and their shopping and disposing attributes, as shown in Table 4, were investigated through the chi square statistical technique. In this study shows that shopping frequency is correlated with education $\left(\mathrm{x}^{2}=15.50, \mathrm{p}\right.$ $=0.01)$, income level $\left(x^{2}=220.11, p=0.00\right)$, and number of children $\left(x^{2}=57.16, p=0.00\right)$. The table shows that cost per shopping is related with education $\left(x^{2}=43.96, p=0.00\right)$, income level $\left(x^{2}=171.56, p=0.00\right)$, and number of children $\left(x^{2}=20.43, p=0.01\right)$. It was found that there are relations between types of disposing clothes and gender $\left(x^{2}=10.33, p=0.05\right)$, education $\left(x^{2}=\right.$ $80.17, \mathrm{p}=0.00)$, income level $\left(\mathrm{x}^{2}=117.96, \mathrm{p}=0.00\right)$, and number of children $\left(\mathrm{x}^{2}=69.01, \mathrm{p}=\right.$ $0.00)$. The table indicates that there are associations between the decision making to purchase ecofriendly clothes and education $\left(x^{2}=33.12, p=0.00\right)$, income level $\left(x^{2}=33.36, p=0.00\right)$, and number of children $\left(x^{2}=44.16, p=0.00\right)$. Also, there are relationships between the willingness to purchase multifunctional children's clothes and education $\left(x^{2}=38.17, p=0.00\right)$, income level $\left(x^{2}\right.$ $=31.95, \mathrm{p}=0.00)$, and number of children $\left(\mathrm{x}^{2}=42.88, \mathrm{p}=0.00\right)$.

There is no strong correlation between the gender variable and the shopping variables. Income is the most important component among demographic variables that have been linked to factors in clothing buying and disposal. Surprisingly, all demographic variables of respondents, except gender, have a strong correlation with the eco-friendly and multifunctionality of children's clothes. 
Table 4: The correlations between demographic variables and patterns of consumption and disposing, $* \mathrm{p}=0: 000 ; * * \mathrm{p}=0.01 ; * * * \mathrm{p}=0.05$

\begin{tabular}{lllcccccc}
\hline \hline & \multicolumn{2}{c}{ Gender } & \multicolumn{2}{c}{ Education } & \multicolumn{2}{c}{ Income } & \multicolumn{2}{c}{ No. of Children } \\
\hline \multicolumn{1}{c}{ Factors } & $\mathrm{X}^{2}$ & $\mathrm{df}$ & $\mathrm{X}^{2}$ & $\mathrm{df}$ & $\mathrm{X}^{2}$ & $\mathrm{df}$ & $\mathrm{X}^{2}$ & $\mathrm{df}$ \\
\hline Shopping Frequency & 15.37 & 4 & $15.50^{* *}$ & 6 & $220.11^{*}$ & 16 & $57.16^{*}$ & 12 \\
Shopping Cost & 12.18 & 2 & $43.96^{*}$ & 15 & $171.56^{*}$ & 20 & $20.43^{* *}$ & 6 \\
$\begin{array}{l}\text { Types of disposing } \\
\text { Eco-friendly clothing }\end{array}$ & $10.33^{* * *}$ & 5 & $80.17^{*}$ & 15 & $117.96^{*}$ & 30 & $69.01^{*}$ & 15 \\
$\begin{array}{l}\text { shopping } \\
\text { Multifunctional shopping }\end{array}$ & 1.46 & 2 & $33.12^{*}$ & 6 & $33.36^{*}$ & 12 & $44.16^{*}$ & 12 \\
\hline \hline
\end{tabular}

Table 5: The correlations between demographic variables of parents those have experience with eco-friendly children clothing and shopping variables, $* \mathrm{p}=0: 000 ; * * \mathrm{p}=0.01 ; * * * \mathrm{p}=0: 05$

\begin{tabular}{lllllllll}
\hline \hline & \multicolumn{2}{c}{ Gender } & \multicolumn{3}{c}{ Education } & \multicolumn{2}{c}{ Income } & \multicolumn{2}{c}{ No. of Children } \\
\hline Factors & $\mathrm{X}^{2}$ & $\mathrm{df}$ & $\mathrm{X}^{2}$ & $\mathrm{df}$ & $\mathrm{X}^{2}$ & $\mathrm{df}$ & $\mathrm{X}^{2}$ & $\mathrm{df}$ \\
\hline Quality & $20.23^{* *}$ & 9 & $47.37^{*}$ & 6 & $28.28^{* *}$ & 12 & $19.14^{* *}$ & 6 \\
Design and colour & $46.11^{*}$ & 9 & $39.65^{*}$ & 6 & $49.00^{*}$ & 9 & $12.74^{* *}$ & 6 \\
Price & $53.59^{*}$ & 18 & $53.20^{*}$ & 12 & $46.69^{*}$ & 18 & $40.62^{*}$ & 12 \\
Health issues & $6.98^{* * *}$ & 2 & $37.29^{*}$ & 9 & $19.25^{*}$ & 6 & $28.40^{* *}$ & 12 \\
$\begin{array}{l}\text { Environmental } \\
\text { Protection }\end{array}$ & 11.23 & 3 & $58.43^{*}$ & 12 & $77.22^{*}$ & 18 & $24.74 * *$ & 9 \\
\hline \hline
\end{tabular}

The factors that affect parents' shopping experience for sustainable children clothing are presented in Table 5. The most important factors affected to purchase sustainable clothes in terms of means are price, quality, design, environmental protection, and health issues. However, there is no strong correlation between quality, health issues and environmental protection with demographic characteristics of the respondents, especially in gender and number of children.

The table indicates that quality is related to gender $\left(\mathrm{x}^{2}=20.23, \mathrm{p}=0.01\right)$, education $\left(\mathrm{x}^{2}=47.37, \mathrm{p}\right.$ $=0.00)$, income level $\left(x^{2}=28.28, p=0.01\right)$, and number of children $\left(x^{2}=19.14, p=0.01\right)$. There is a correlation between design of clothing and with gender $\left(x^{2}=46.11, p=0.00\right)$, education $\left(x^{2}=\right.$ 39.65, $\mathrm{p}=0.00)$, income level $\left(\mathrm{x}^{2}=49, \mathrm{p}=0.00\right)$, and number of children $\left(\mathrm{x}^{2}=12.74, \mathrm{p}=0.05\right)$. Price is corelated with respondents' gender $\left(x^{2}=53.59, p=0.00\right)$, education $\left(x^{2}=53.02, p=0.00\right)$, income level $\left(x^{2}=46.69, p=0.00\right)$, and number of children $\left(x^{2}=40.62, p=0.00\right)$. Also, the table shows that health issues correlate with gender $\left(\mathrm{x}^{2}=6.98, \mathrm{p}=0.05\right)$, education $\left(\mathrm{x}^{2}=37.29, \mathrm{p}=\right.$ $0.00)$, income level $\left(x^{2}=19.25, \mathrm{p}=0.00\right)$, and number of children $\left(\mathrm{x}^{2}=28.40, \mathrm{p}=0.00\right)$. Environmental protection is associated with education $\left(\mathrm{x}^{2}=58.43, \mathrm{p}=0.00\right)$, income level $\left(\mathrm{x}^{2}=\right.$ $77.22, \mathrm{p}=0.00)$, and number of children $\left(\mathrm{x}^{2}=24.74, \mathrm{p}=0.01\right)$.

Table 6 indicates that expensive is associated with gender $\left(x^{2}=7.01, p=0.05\right)$, income level $\left(x^{2}=\right.$ $78.70, p=0.00)$, and number of children $\left(x^{2}=47.56, p=0.00\right)$. There is a correlation between poor quality and gender $\left(\mathrm{x}^{2}=31.15, \mathrm{p}=0.00\right)$, education $\left(\mathrm{x}^{2}=17.56, \mathrm{p}=0.01\right)$, income level $\left(\mathrm{x}^{2}=\right.$ $27.08, \mathrm{p}=0.00)$, and number of children $\left(\mathrm{x}^{2}=36.29, \mathrm{p}=0.00\right)$. Lack of knowledge is linked to 
respondents with education $\left(\mathrm{x}^{2}=30.71, \mathrm{p}=0.00\right)$. Besides, Table 6 shows that no available property of sustainable clothes correlates with education $\left(x^{2}=22.18, p=0.01\right)$ and income $\left(x^{2}=\right.$ $61.99, \mathrm{p}=0.00)$. However, there is no strong correlation between the attributes of sustainable clothing such as too expensive, poor quality and lack of knowledge with gender of the respondents.

Table 6: The correlations between demographic variables of parents those do not have experience with eco-friendly children clothing and shopping variables, ${ }^{*} \mathrm{p}=0: 000 ; * * \mathrm{p}=0.01$; $* * * \mathrm{p}=0: 05$

\begin{tabular}{lllllllll}
\hline \hline & Gender & & Education & & Income & \multicolumn{3}{c}{$\begin{array}{l}\text { No. of } \\
\text { Children }\end{array}$} \\
\hline Factors & $\mathrm{X}^{2}$ & $\mathrm{df}$ & $\mathrm{X}^{2}$ & $\mathrm{df}$ & $\mathrm{X}^{2}$ & $\mathrm{df}$ & $\mathrm{X}^{2}$ & $\mathrm{df}$ \\
\hline Expensive & $7.01^{* * *}$ & 3 & 5.71 & 3 & $78.70^{*}$ & 12 & $47.56^{*}$ & 18 \\
Poor quality & $31.15^{*}$ & 9 & $17.56^{* *}$ & 6 & $27.08^{*}$ & 9 & $36.29^{*}$ & 18 \\
Lack of knowledge & 20.48 & 6 & $30.71^{*}$ & 9 & 18.82 & 6 & 27.24 & 6 \\
Not available & 58.876 & 6 & $22.18^{* *}$ & 12 & $61.99^{*}$ & 9 & 6.47 & 3 \\
\hline \hline
\end{tabular}

Table 7 showed that most of the parents preferred to have variations of children clothing in their children wardrobe. Design 1 (cartoon boy overall), Design 6 (cartoon girl overall), Design 7 (cartoon shirt) and Design 10 (cartoon sleeveless shirt) were more popular items with a good mean more than 4.

Through confirmatory factor analysis (CFA), the study aims to identify whether the proposed model meets the standards of reliability and validity. The reliability was tested by composite reliability $(\mathrm{CR})$ and Cronbach alpha $(\alpha)$ with both more than 0.70 . According to George and Mallery (2003), this study found support to combine the items under each measure into the intended multi-item scale, with high reliability $(\alpha \geqslant 0.7$ ) for all variables. Reliability coefficients indicated appropriate internal consistency for children's clothing disposal and consumption $(\alpha=0.78)$, parent's experience toward sustainable children's clothing $(\alpha=0.72)$, parents' opinion on the design properties of children clothing $(\alpha=0.79)$ and determinants of buying intent on environmentally friendly children's clothing $(\alpha=0.71)$ that significant at the level 0.001 . The validity of the scale items was assessed with factor loadings and Average Variance Extracted (AVE) which were both greater than 0.50 . It was found that the values of factor loading were high on their respective variables. In general, factor loading over 0.50 is classified as a "strong" item loading (George \& Mallery, 2003). Second, the AVE for the four measures is more than 0.5, indicating variable-level convergent validity. The results are summarized in Table 8.

Table 7: Descriptive statistics of parents' opinion on the design properties of children clothing $(\mathrm{N}=144)$

\begin{tabular}{cccc}
\hline \hline \multicolumn{2}{c}{ Please rank each item that you most prefer to purchase for your children: } \\
\hline No. & $\mathbf{2}$ & \\
& & \\
Prototype & & & \\
& $\mathbf{4 . 5 4}$ & 3.98 & Simple Shirt and Trouser \\
Mean & 0.62 & 0.81 & 4.09 \\
Std & Cartoon Overall, Trouser and Shirt & 0.79
\end{tabular}




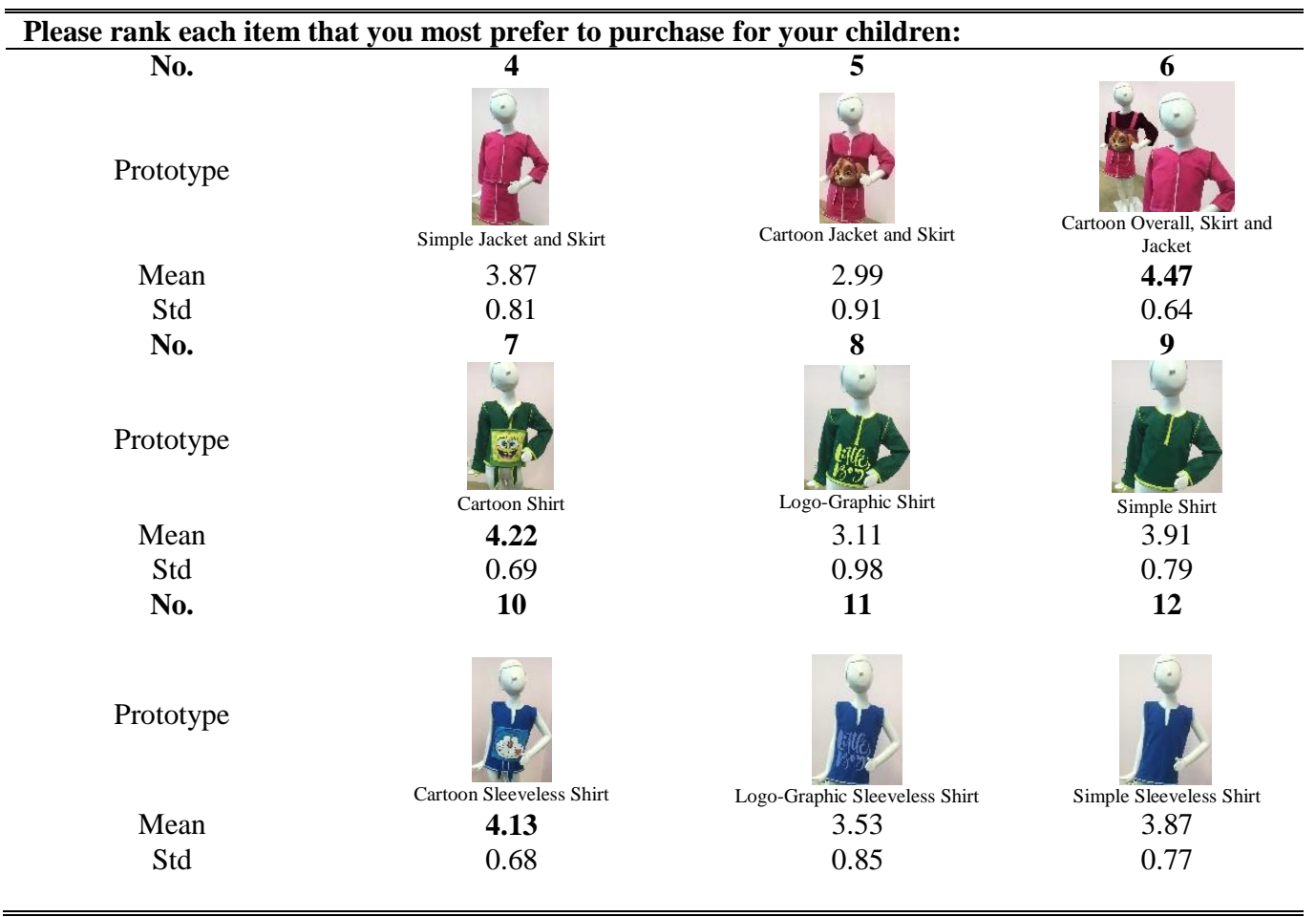

Based on the analysis developed in the methodology phase and construct hypotheses, the authors decided to assess the validity of the structural model for this study. The proposed hypotheses were tested through the structural equation modelling (SEM) technique. The results of the structural model achieved from SmartPLS are presented in Figure 2. The validity of the structural model is evaluated using effect size, path coefficients ( $\beta$-value) and t-statistic value. The coefficient of determination measures the overall effect size explained in the endogenous variable for the structural model and is thus a measure of the model's predictive accuracy. The criteria suggested for interpreting the effect size is given as follows: small effect $<0.02,0.02<$ medium effect $<0.15$ and the large effect $>0.35(\mathrm{p}<0.05)$.

Table 8: The empirical results of reliability and validity $(\mathrm{N}=144)$

\begin{tabular}{|c|c|c|c|c|}
\hline Variables & $\begin{array}{c}\text { Factor } \\
\text { loading } \\
(\geq \mathbf{0 . 7})\end{array}$ & $\begin{array}{c}\alpha \\
(\geq 0.7\end{array}$ & $\mathrm{CR}(\geq 0.7)$ & $\begin{array}{c}\text { AVE } \\
(\geq 0.5)\end{array}$ \\
\hline $\begin{array}{l}\text { Children's clothing disposal and consumption } \\
\text {-I donate to charity organizations or give away } \\
\text {-I reuse for a new purpose } \\
\text {-I throw away into any garbage bins available } \\
\text {-I purchase because of child growth and change in } \\
\text { height and weight } \\
\text {-I purchase children's clothing for only one event }\end{array}$ & $\begin{array}{l}0.81 \\
0.73 \\
\\
0.91 \\
\\
0.71\end{array}$ & 0.78 & 0.75 & 0.63 \\
\hline
\end{tabular}


-Good quality

-Design and colour

-Price

-Health issues

Parents' opinion on the design properties of children clothing: I prefer to purchase

-Simple children's clothes

-Happy Colours (bright and joyful)

-Multifunctional usage

Determinants buying intent on environmentally friendly children's clothing

-I am going to buy sustainable children's clothes if I

happen to see them in a store.

-I would intend to use sustainable children's clothes

Eco-fashion clothes.
0.76

0.73

0.70

0.74

$\begin{array}{lll}0.79 & 0.85 & 0.65\end{array}$

0.81

0.91

0.75

$\begin{array}{lll}0.71 & 0.82 & 0.64\end{array}$

0.73

0.70

Figure 2: Measurement model

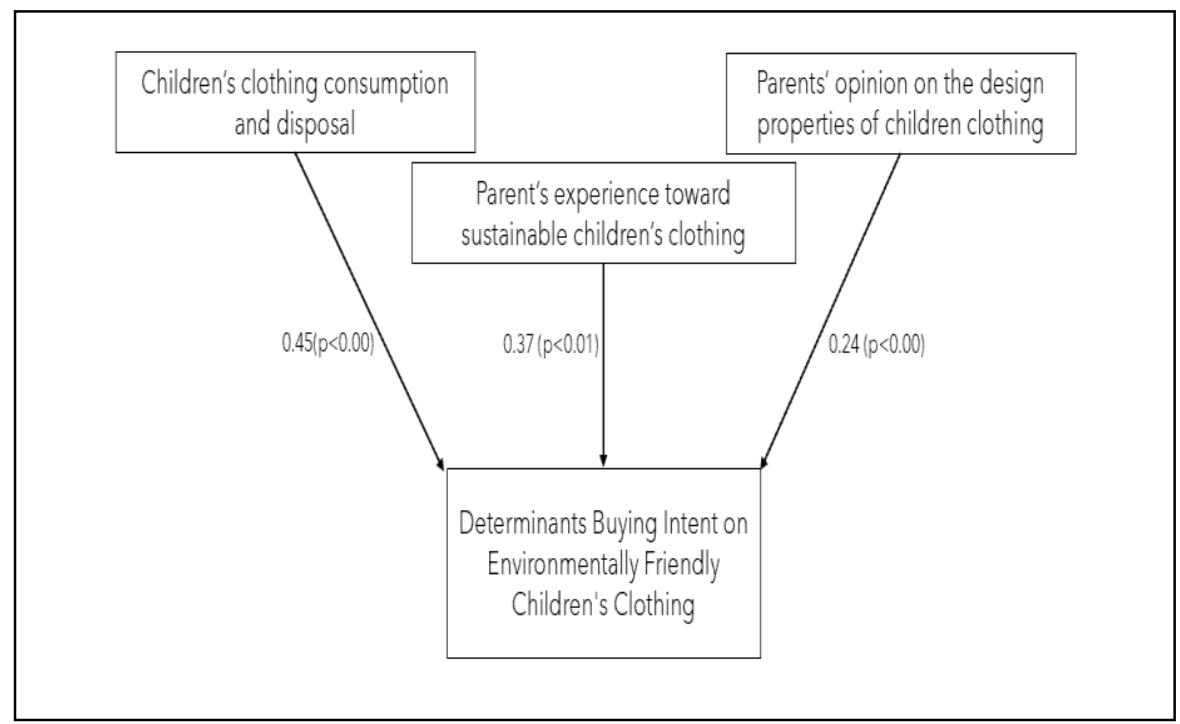

Therefore, in this study two factors had a large effect. The higher $\beta$-value shows the stronger impact of a predictor independent variable on the dependent variable. Figure 2 shows that the $\beta$ value of children's clothing consumption and disposal has the highest co-efficient value of 0.45 on the determinants of buying intent on environmentally friendly children's clothing. All hypotheses were supported. Therefore, the following variables had a positive association with the determinants of buying intent on environmentally friendly children's clothing: children's clothing consumption and disposal of clothes $\left(\mathrm{H}_{1}\right)$, parent's experience toward sustainable children's clothing $\left(\mathrm{H}_{2}\right)$ and parents' opinion on the design properties of children clothing $\left(\mathrm{H}_{3}\right)$. The results of the SEM modelling indicated that "children's clothing consumption and disposal of clothes" and "parent's experience toward sustainable children's clothing" have a strong effect on the determinants of buying intent on environmentally friendly children's clothing. Finally, parents' opinion on the design properties of children clothing plays an important role as predictors variable for the 
determinants buying intent which supports $\mathrm{H}_{3}$. Results of hypotheses testing are summarized in Table 9.

Table 9: Results of hypotheses testing, $\mathrm{p}<0.01 * *, \mathrm{p}<0.000 * * *$

\begin{tabular}{lcccccc}
\hline \multicolumn{1}{c}{ Hypothesis } & $\mathbf{f 2}$ & Effect & $\boldsymbol{\beta}$ & S.E & $\begin{array}{c}\text { t } \\
\text { value }\end{array}$ & Decision \\
\hline $\begin{array}{l}\text { H1: Children's clothing consumption and disposal } \\
\rightarrow \text { Determinants buying intent }\end{array}$ & 0.58 & Large & 0.45 & 0.09 & 7.46 & $* * *$ \\
$\begin{array}{l}\text { H2: Parent's experience toward sustainable } \\
\text { children's clothing } \rightarrow \text { Determinants buying intent }\end{array}$ & 0.54 & Large & 0.37 & 0.11 & 5.11 & $* *$ \\
$\begin{array}{l}\text { H3: Parents' opinion on the design properties of } \\
\text { children clothing } \rightarrow \text { Determinants buying intent }\end{array}$ & 0.23 & Medium & 0.24 & 0.08 & 3.22 & $* * *$ \\
\hline \hline
\end{tabular}

\section{DISCUSSION AND CONCLUSION}

The research has studied the challenges of purchasing, consumption and disposal of children's clothes based on the concept of eco-fashion. Each year there are growing numbers of parents purchasing new items and disposing of old clothes to suit their children's changing needs. Moreover, these days eco-friendly fashion is widely promoted to influence and encourage parents to purchase. The interest of consumers in environmental-friendly clothing has gained traction, especially the demand for organic cotton products. Therefore, the study of the behaviour of parents concerning the appropriate way of managing children's clothing can enable clothing companies to establish marketing strategies. Most customers purchase their children's clothing at least once every four to five months. Approximately half of the parents spend RM 51-100 per shopping for children's clothing. This shows that consumers are willing to purchase at lower prices and most of them purchase quarterly.

Most parents determine the buying decisions for their children. Children, however, always determine for themselves. Findings show that most parents expressed their interest in having a variation of children's clothing, particularly in cartoon design types. It has been found that there is a significant relationship between the respondent's demographic characteristics and their children's shopping behaviour. The findings show that shopping frequency is linked to household income and the number of children rather than education. The cost per shopping is associated with education and income level, as well as the number of children. The study showed that there are relationships between the different ways they choose to dispose of children's clothes and education, number of children and income level of the respondents. The shopping behaviour for purchasing sustainable children's clothing is significantly related to the respondents' education, income level, and the number of children. No significant correlations were found between the factors of shopping and disposal of children's clothes with the gender of respondents in the study. This is in line with some findings by Haluk Köksal (2007). The most important factors affecting parents' decisions towards shopping for sustainable children's clothing are price, quality, design, colour and health issues, which are consistent with previous studies by Haluk Köksal (2007) and Gam et al. (2010). However, lack of knowledge or awareness and unavailability of such clothes were most challenging among parents. In this study, education was also an important factor for parents, which supports the finding of the study carried out by Jalil and Shaharuddin (2019b). 
Multifunctional clothing can be considered as a novel idea in fashion design that helps to prevent clothing consumption problems and reduces clothing waste. Based on the findings, parents stated that the main reason for the disposal of children's clothes is $(31.2 \%)$ child growth and change in height and weight. Moreover, they purchase clothes such as shorts, shirts, t-shirt, sleeveless shirts, etc. every 3 to 4 months in the year. Therefore, the concept of multifunctional clothes can help parents reduce the disposal of clothes due to children rapid growth by converting them to other functions such as a bag for more usage. The survey's results show that most parents $(84.7 \%)$ would purchase multifunctional children's clothes if they were available in the market. The data which refers to the questionnaire demonstrates that children's clothing is a significant issue among parents. Therefore, multifunctional clothing would be a favourable solution. Recently, there are children's clothing that is considered overly designed and not age-appropriate for children. Indeed, it does not encourage children to interact with their clothing in order to stimulate creativity in the way that they dress. Hence, multifunctional clothes can be a solution to this issue.

Multifunctional clothing is part of fast fashion products, and like other products, affect the environment. Based on the findings, factors such as fair price, good quality and stylish sustainable children's clothing are the main concern when purchasing the clothes. Also, respondents perceived that eco-fashion clothing is first, not commonly available in the clothing market (87.5\%), and secondly, the design is limited, poor in quality and expensive. Hence, creating multifunctional children's clothing with consideration of sustainable characteristics during production and using sustainable materials is the definitive idea of this study which is supported by findings of Gam et al. (2010). This approach is used to support the children's daily choice of clothes while still appearing fashionable at a lower price and with good quality. The study also found that multifunctional children's clothing is not a common concept in society, however, parents are interested to purchase them. Therefore, this supports the finding of the study carried out by Gam et al. (2010) and Koo et al. (2014). This study shows that the two factors that have a large effect on buying intent on environmentally friendly children's clothing are "Children's clothing consumption and disposal" and "parent's experience toward sustainable children's clothing". However, "parents' opinion on the design properties of children's clothing" is also a factor in the intent of purchasing sustainable children's clothing. Hence, sustainable attention in children's clothing is extended to consumption pattern, design, and visualization. It is concluded that in sustainable children's clothing, design and colour are also considered as main factors, along with quality, price, and health issues in intention to purchase. Other than that, the findings show that parents prefer to donate as a charity, give away to family and friends, or reuse clothing items. Only a small group would discard clothing due to the poor quality and condition. The main reason for disposing of unwanted children's clothing is ruined clothes or clothing that no longer fit. The study revealed that fast fashion is taking over the children's clothing industry. Fashionable property and purchasing clothes for only a single use is not the main concern among parents in shopping. Hence, multifunctional children's clothing may lead to extending the usage of children's clothes. This study has attempted to explore the parent's determinants of buying intent toward sustainable children's clothing in Malaysia, albeit it has limitations in sampling methods. A relatively low number of participants in Malaysia became the principal limitation of this research, as the target of this study are mothers with children ages 3 to 7 years old. Hence, more studies with a sufficient population sample would be needed. The lack of variety in sustainable children's products in Malaysia was a substantial challenge. Some children's clothing companies such as The Little Clothing Shop, Real.m, and Kooshboo produce sustainable products. Even so, the limited 
children's clothing industry in Malaysia, especially in a sustainable manner, is still relatively small. Thus, the textile and clothing industry needs to improve the development and distribution of such clothing to the market.

Future research may also look at eco-fabrics, such as organic cotton, which has the potential for environmentally sustainable clothing design. The fashion industry must develop sustainable products, where the constant reassessment of the expectation of environmental-friendly clothing is essential. Therefore, it is important to investigate children's acquiring behaviour and sustainable design concepts. These will give business decision-makers a clearer understanding of how effective strategies can be built for competitive advantages in the rising market of the children's apparel industry.

\section{ACKNOWLEDGEMENT}

This paper was supported by P.Ramlee Chair research grant No. F03/PRC/1929/2019.

\section{REFERENCES}

Berry, H. S., Ismail, R. K., Al-Daadi, S. E., Badr, S. I. O., Mesbah, Y. O., \& Dabbagh, M. A. (2020). Measuring Saudi Mothers' Awareness of Sustainable Children's Clothing. Open Journal of Social Sciences, 8(11), 244-262.

Bezerra, G., Carvalho, M., Rocha, M., \& Xu, B. (2017). Anthropometry for children's clothing: difficulties and limitations. Paper presented at the IOP Conference Series: Materials Science and Engineering (pp 1-6). United Kingdom: IOP Publishing.

Cao, H., Chang, R., Kallal, J., Manalo, G., McCord, J., Shaw, J., \& Starner, H. (2014). Adaptable apparel: a sustainable design solution for excess apparel consumption problem. Journal of Fashion Marketing and Management, 18(1), 52-69.

Chong, C. T. (2007). Research on the characteristics of cartoon characters for Malaysian children (Unpublished Master Thesis). Universiti Malaysia Sarawak, Malaysia.

Cui, Y. M., Zhong, H., \& Zhu, D. H. (2011). Classify Application and Development Trend of Children Clothing Material Modeling and Style. Paper presented at the Advanced Materials Research (pp 534-538). Switzerland: Trans Tech Publications Ltd.

Cunha, J., \& A. Broega. (2009). Designing multifunctional textile fashion products. in AUTEX 2009: 9th World Textile Conference.

Delice, A. (2010). The sampling issues in Quantitative Research. Education Science: Theory Practice, 10(4), 2001-2018.

Gam, H. J., Cao, H., Farr, C., \& Kang, M. (2010). Quest for the eco-apparel market: a study of mothers' willingness to purchase organic cotton clothing for their children. International Journal of Consumer Studies, 34(6), 648-656.

George, D. \& M. Mallery. (2003). Reliability analysis. SPSS for Windows, step by step: a simple guide and reference. Boston: Allyn \& Bacon.

Haluk Köksal, M. (2007). Consumer behaviour and preferences regarding children's clothing in Turkey. Journal of Fashion Marketing and Management: An International Journal, 11(1), 69-81. 
Jalil, M. H., \& Shaharuddin, S. S. (2019a). Adopting C2CAD Model to Eco Capsule Wardrobe Design. International Journal of Scientific \& Technology Research, 8(12), 1224-1233.

Jalil, M. H., \& Shaharuddin, S. S. (2019b). Consumer Purchase Behaviour of Eco-Fashion Clothes as A Trend to Reduce Clothing Waste. International Journal of Innovative Technology and Exploring Engineering, 8(12), 4224-4233.

Jalil, M. H., \& Shaharuddin, S. S. (2020). Fashion Designer Behavior Toward Eco-Fashion Design. Journal of Visual Art and Design, 12(1), 1-24.

Kamis, A., Suhairom, N., Jamaluddin, R., Syamwil, R., \& Ahmad Puad, F. (2018). Environmentally Sustainable Apparel: Recycle, Repairing and Reuse Apparel. The International Journal of Social Sciences and Humanities Invention, 5(1), 4249-4257.

Koo, H. S., Dunne, L., \& Bye, E. (2014). Design functions in transformable garments for sustainability. International Journal of Fashion Design, Technology and Education, 7(1), 10-20.

Lindstrom, M., Seybold, P. B., \& Hoyle, D. B. (2004). Brandchild: remarkable insights into the minds of today's global kids and their relationship with brands: Kogan Page Publishers.

Malaysia External Trade Development Corporation. (2016). Trade Performance: December 2016 and January-December 2016. www.matrade.gov.my/en/malaysia-tradeperformance/3758-trade-performance-december-2016-and-january-december-2016

Rahman, O., \& Gong, M. (2016). Sustainable practices and transformable fashion design-Chinese professional and consumer perspectives. International Journal of Fashion Design, Technology and Education, 9(3), 233-247.

Rhee, J. \& Johnson K. K. (2019). 'The wardrobe diet': teaching sustainable consumption through experience with undergraduates in the USA. International Journal of Fashion Design, Technology and Education, 1(1), 1-10.

Sego, T. (2010). Mothers' experiences related to the disposal of children's clothing and gear: keeping Mister Clatters but tossing broken Barbie. Journal of Consumer Behaviour: An International Research Review, 9(1), 57-68.

Shaharuddin, S. S., \& Jalil, M. H. (2021). Multifunctional Children Clothing Design Process Based on the Eco-Fashion Design Model. Journal of Visual Art and Design, 13(1), 35-47.

Statista. (2020). Children's Apparel. www.statista.com/outlook/cmo/apparel/childrensapparel/worldwide

Thompson, S. K. (2006). Targeted random walk designs. Survey Methodology, 32(1), 11-22.

Yu, L., Westland, S., Li, Z., Pan, Q., Shin, M. J., \& Won, S. (2018). The role of individual colour preferences in consumer purchase decisions. Color Research \& Application, 43(2), 258267.

Zhang, L. (2018). Study on Children Product Design and Development Based on Fashion Consumption. Paper presented at the 2017 7th International Conference on Social science and Education Research (SSER2017) (pp. 194-197). Paris: Atlantis Press. 